\title{
A Conceptual Framework for the Influence of Entrepreneurial Orientation and Environmental Dynamism on Marketing Innovation Performance in SMEs
}

\section{Maikudi Shehu Musawa* and Kamilah Ahmad}

Faculty of Technology Management and Business, Universiti Tunn Hussein Onn Malaysia, Malaysia

${ }^{*}$ Corresponding author: Musawa MS, Faculty of Technology Management and Business, Universiti Tunn Hussein Onn Malaysia, Malaysia, Tel: 607453 7000; E-mail: maikudis@gmail.com

Received date: May 25 2018; Accepted date: June 25, 2018; Published date: July 02, 2018

Copyright: ( 2018 Musawa MS et al. This is an open-access article distributed under the terms of the Creative Commons Attribution License, which permits unrestricted use, distribution, and reproduction in any medium, provided the original author and source are credited.

\begin{abstract}
The main purpose of this paper is to provide a conceptual framework on the role of entrepreneurial orientation (EO) in enhancing marketing innovation performance in the context of Small and Medium Enterprises (SMEs) as it has been recommended to improve SMEs performance as a result of adopting the three principal business procedure. The paper was motivated by the importance of SMEs towards job creation, poverty reduction and economic development in most economies particularly among the developing countries. The SMEs sector has more flexibility in the face of environmental change when worldwide competition is becoming more powerful. At this edge of an economy, the level of innovation is the key to their success, growth, and survival. Thus achieving a workable marketing innovation system as well as improving services delivery are becoming critical. The existing literature demonstrates that the effectiveness of SMEs is reliant on the state of environmental influences. The environmental dynamism shapes the achievement of SMEs objectives and overall innovation performance. This study proposes the research framework on the effect of EO on marketing innovation performance. As postulated in the study, EO standin through the five measurements of autonomy, innovativeness, risk-taking, proactiveness and competitive aggressiveness enables a firm to act resourcefully and organize its resources in a way that contributes to marketing innovation performance due to the tendency to act autonomously, the trend to be aggressive toward competition, to proactively pursue market opportunities, and to have the willingness to innovate and bear the risk. On this basis, this study further postulated that environmental dynamism moderates the relationships between the five dimensions of $\mathrm{EO}$ and marketing innovation performance.
\end{abstract}

Keywords: Entrepreneurial Orientation; Environmental Dynamism; SMEs; Marketing Innovation Performance

\section{Introduction}

Entrepreneurial orientation (EO) has been distinguished as an important factor for management success and has been established to lead to greater performance $[1,2]$. Additionally, it was argued that entrepreneurial firms achieve well than those with lower levels of EO [3]. Advanced levels of EO permits businesses to take the competence to detect and snatch opportunities in a way that differentiates them from non-entrepreneurial firms [2]. Some governments have created appropriate initiatives to make business environment conducive for SMEs to flourish. There has been a remarkable improvement in the SMEs environment following to the creation of appropriate initiatives to make business environment conducive for SMEs to flourish. For example, the Federal Government of Nigeria has made easier for SMEs to access collateral free loan capital in micro financial institutions, at very low-interest rates, created market opportunities for SMEs products and made a protection policy to local firms against foreign firms [4]. Ireland et al. [5] showed that SMEs are effective in identifying opportunities but less successful in developing competitive advantages. It is surprising to note that, despite such good business environment. SMEs are still experiencing poor performance trends hence failure to survive or even grow to become big firms. Many challenges which were thought to be responsible for the obvious poor performance of SMEs have been widely studied and some recommendations have already been implemented, yet no appealing improvement has been realized.

Scholars and practitioners comprehend well about the importance of SMEs, but still, studies on SMEs performances have explained certain major weaknesses that exist. The majority of the studies have identified many barriers and constraints for the growth of the SMEs performance. To date 3 out of every 5 SMEs established fail within a period of fewer than five years from their establishment and the surviving firms are usually stagnant [6]. According to entry of business is not a problem for SMEs, however, its growth is characterized by stagnancy and poor performance. SMEs are also facing constraints in differentiating their products, changing their business model, internal financial resources, and technical capabilities [7]. These problems are responsible for the failure of SMEs and obviously, there are other problems also with some unique features in every business. Their major obstacles in process of growth are due to limited:-

- Financial resources [8],

- Managerial and technical expertise,

- knowledge of environmental aspects and inadequate infrastructure,

- Resources to implement information systems.

It has been found that SMEs are resource-constrained and face a liability of compactness [9]. Limited resources and underdeveloped marketing skills often lead to unsophisticated and unplanned marketing activities. Apart from that enterprise's negligence to 
innovation are also responsible for the failure of SMEs [10]. Many SMEs literature has not linked innovation performance of SMEs as the potential outcome of dynamic interactions of EO and environmental dynamism. Failure of SMEs in early stages of business its life cycle and stagnancy indicate poor innovation performance [11]. Marketing innovation is recognized by way of its uniqueness in the application of the three main business practices of (a) product growth supervision, (b) supply chain organization, and (c) consumer relationship supervision. Marketing innovation lead to novel product introductions, quicker practicing of fresh product concepts, and improve sales, and boost cost-effectiveness [12]. Additionally, Marketing innovation proffer business the prospect to improved revenue and cash movement from different sales networks, enhanced module feature and value over management input, and decrease in client service costs over technology, subcontracting, or rationalized working processes. Therefore, marketing innovation performance is crucial to the success and survival of SMEs.

Previous researchers demonstrate that innovative SMEs firms are further expected to be the leading industry to introduce new products and accomplish better in the sectors they represent. Nonentrepreneurial SMEs firms, on the different, are less likely to be forerunners in new product development (NPD) and are less likely to be successful in their respective sectors. Undoubtedly, with the constraints facing SMEs, especially in the context of emerging economies it is becoming crucial and urgent for both scholars and entrepreneurs to understand the factors which contribute to achieving better business performance. Research has upheld the idea that firms should pay close attention to the association which exists between the level of innovation and the level of change and complexity within the industry [13].

The purpose of this paper is to examine the effect of EO and environmental dynamism on marketing innovation performance in SMEs. As markets develop to meet the altering perceptions and favorites of clients, the type of properties necessary to SMEs in these extremely modest markets may change as well. Any form this change may take is for modest markets, to become more greatly confined, hence being able to forestall tendencies in the market may be a cherished resource for firms expecting to improve client reliability and improved sales. This transformation may offer SMEs firms with the prospect to improve performance as research has shown that in other industries, firms that are conscious of chances and are able to react to these openings have better performance outcomes [14]. The quest for new opportunities and the consequent improvement of new products recommends that an entrepreneurial orientation may contribute to innovation success $[5,15]$.

This paper will first, review the literature on EO, environmental dynamism and as well as marketing innovation performance. Second, cultivate a conceptual model to show the relationships between EO perceived the moderating role of environmental dynamism on EO and marketing innovation performance, hypotheses were presented for each relationship. Finally, the researcher concluded by proposing some managerial implications and directions for future research.

\section{Entrepreneurship Orientation}

To withstand innovation and achievement in markets, it is vital for SMEs to have assets, processes, and structures that contribute to its flexibility and opportunities for identifying and securing [16]. Lumpkin and Dess [17] defined entrepreneurial orientation by way of the procedures, practices, and undertakings of assessment making that facilitates new entry. It is a practice of entrepreneurship that is identified and acknowledged for its five dimensions namely innovativeness, risk taking, proactiveness, competitive aggressiveness, and autonomy. EO can be described as the readiness of the SMEs to take inventive activities and attractive risks to emanate new products/ services and to introduce new markets, and proactively make a move before its rivals in availing of new opportunities in the market [18]. This definition covers all dimensions of $\mathrm{EO}$ that is an extremely intercorrelated with each other, which compel to combining these dimensions into one single concept [18].

EO has newly become a very popular research field. One could argue that this popularity of EO is based on the environment being described as complex and uncertain. In order for firms to compete in such conditions, further knowledge within entrepreneurship is needed. Considering the good nature of today's business environment, SMEs need to devise means of survival. Being entrepreneurial-oriented simply means being prepared for the trials that the business environment poses, and to constantly change plans to overcome those challenges. It is supreme to SMEs success in the competitive atmosphere [19]. Everything about EO is either meant at appealing new customers or keeping existing ones, ahead of competitors. It represents all the strategies that define SMEs method to the search of its goals in a competitive environment. EO allows SMEs to cultivate concepts and realize them in the form of new products and services, participate in risky projects, forecast future requirements, and find new market opportunities. These structures in SMEs can be positive when they face various challenges from the competitive environment.

To active abilities, the SMEs owner-manager needs to form EO in business. Part of the challenges faced by SMEs is how the business is capable of meeting market demand. According to Gima and Anthony [20] organizations with high EO, abilities tend to be able to perform better than the competitors in terms of (1) market share, (2) speed in entering the market, and (3) the level of product quality. SMEs should be able to make a strategic move as the basis for making the right decisions in order to survive and have high competitiveness. The higher the EO of the enterprise, then the likelihoods of the business to meet the market demand would be superior. EO becomes the attention of its own for SMEs, especially in the use of the chances and resources to the type of business [21].

From the standpoint of entrepreneurship, SMEs firms must differentiate themselves from their rivals, have more EO and find ways to achieve a sustainable development, for example, through marketing innovation performance. EO has become considerable variable, which can foster the marketing innovation performance of SMEs. This concept explains a strategic posture in the long term through engaging in product innovation, undertaking risky ventures and proactive action for firm performance [22].

\section{The Moderating Role of Environmental Dynamism in EO and Marketing Innovation Performance}

The literature indicates that business performance not only depends on innovation strategy but also depends on environmental conditions [22]. Generally, a dynamism refers to the rate of change and the degree of variability of the environment. Hence, SMEs can adopt a marketing innovation performance strategy in a complex and uncertain environment because such an environment offers important opportunities concerning emerging market demands [23,24]. Extant 
research suggests that innovative firms can achieve higher performances in volatile and hostile environments [22,23]. That companies which are able to maintain a high level of innovativeness, even under unfavorable environmental conditions, sustain higher levels of profitability and efficiency.

Certainly, in an environment that is characterized by a significant level of uncertainty and dynamism, SMEs owner-managers may face unclear and difficult situations with few alternative solutions and few evaluation criteria by which to select alternatives [25]. These factors may force SMEs owner-managers to optimize available resources and production processes and to develop solutions by taking concrete actions quickly in order to achieve acceptable or successful performances. In addition, the uncertainty and dynamism of the environment may push SMEs owner-managers to rely on their creative abilities to generate and implement creative solutions and ideas of new products and processes for increased business results [26].

According to the Resource Base View theoretical model, companies which have specific resources and skills will have the competitive edge and thus attain superior performance [27]. Using the same theoretical framework, the success or failure of a firm is understood as being the outcome of how its resources are used, especially its human resources [28]. Experience, knowledge, aptitude, skills, and creativity make up the human resources of all the organization's employees, including SMEs owner managers. Makadok [29] states that the SMEs ownermanagers' and employees' ability to develop new products and processes within the SMEs firm is one of the most important sources of competitive advantage and thus a determining factor for business performance [27].

Nevertheless, it is vital for SMEs firm to provide the needful to support innovation activities. SMEs firms which encourage an innovative environment lead SMEs owner-managers to believe that new technology and more innovation will create value for their firms [30]. This has therefore called for improved EO practices, in order to meet numerous preference of customers and aid marketing innovation performance recognition. SMEs enterprise contending in surroundings where great intensities of vitality are present must have the elasticity to adapt to a varying atmosphere to guarantee structural presence [31]. According to Davis [32] a rapidly changing environment increases risk and unpredictability. A minor level of vitality in an environment designates a possible slowdown of the economy or, under most conditions, an enterprise that is sound besides working in a more steady atmosphere have the advantage of additional stability and certainty of ecological change, as well as superior capability to react and change with the atmosphere. These ecological changes include explosiveness of the firm's market, innovations in the industry, shifts in demand and consumer's preferences, production and service skills as well as ambiguity and irregularity of opponents' behavior in the firm's main industry [33].

Several types of research study the correlation between environmental dynamism and EO of the firm [34-37]. High level of ecological vitality may foster the application of $\mathrm{EO}$ in the firm in order to be more effective in searching for the new opportunities which appear on the market [38].

Aspects leading to outside vitality include reduced product life cycles and increased product diversity, developments in information technology and e-business, and improved overall competition [39]. It is also claimed that ecological vitality leads to undesirable effects on performance due to the difficulty of making correct predictions, appraising changes, evolving timely responses, revising schedules, and increased uncertainty $[40,41]$. Additionally, others researchers declared that market-oriented enterprise with elastic procedures and technology complemented with close client relationship will be able to cope with the trials related to ecological vitality, by improving their performance and outperform their opponents [42,43]. Environmental dynamism could be seen as a tool that will improve business process of SMEs [44]. Therefore, a close association between EO and marketing innovation performance is likely to be facilitated by a higher level of market dynamism since companies with higher innovative behavior are more appropriate to reap potential benefits in such circumstances. Accordingly, this study proposes that:

Hla: There is a positive relationship between environmental dynamism and marketing innovation performance.

H1b: Environmental dynamism moderates the relationship between entrepreneurial orientation and marketing innovation performance.

\section{Marketing Innovation Performance}

Innovation activities indicate the competence of employees of an organization to create new or improved products [45]. Innovation defined by Lee [46] as different services and operations related to business that are new, unique and helpful to prospective customers. Innovation is all about modification, however not all transformation is innovative; the modification must be significant and eloquent to an investor. Three methods of managerial innovation are provided for this study: product innovation, process innovation, and marketing innovation.

\section{Product innovation}

The method of evolving besides getting novel otherwise considerably superior products or services to market has been reliably used in the work to define product innovation [47]. Product innovation is separated into three (1) product line extensions (conversant to the business but fresh to the market), (2) me-too products (conversant to the market but new to the business), and (3) new-to-the-world merchandises (new to both the business and the market). The aim of product innovation is to adapt the ability of the product in some way towards improve value to the customer or the business [48].

\section{Process innovation}

In the oxford handbook for innovation review process innovation as "new or significantly improved methods in the production or manufacturing process". Also, according to the internationally recognized Organization for Economic Cooperation and Development (OECD), process innovation is the application of different or considerably better techniques for invention or supply, to comprise important variations in methods, apparatus, and/or software. To explore marketing innovation there is need to announce the central business processes to operationalize the construct. As, claimed that marketing ought be regarded as an structural self-restraint, and once marketing ability is filled into the central business processes, SMEs performance is considerably improved and marketing activities are well recognized [49-53]. The central business processes are (1) the product development management (PDM) process, (2) the supply chain management (SCM) process, and (3) the customer relationship management (CRM) process, respectively. 


\section{Marketing innovation}

Marketing innovation is "the generation and implementation of new ideas for creating, communicating, and delivering value to customers and managing customer relationships" [54]. This study discusses that marketing innovation must stand established alongside with product innovation. OECD [48], claimed that marketing innovation is "the implementation of a new marketing method involving significant changes in product design or packaging, product placement, product promotion, or pricing,"

Marketing innovations are identified as the introduction of new marketing methods, which include changes in product design, promotional strategies, and price [27]. Examples of marketing innovations in SMEs include the habit of social networking sites in encouraging the industry or client loyalty programs. The recommendation of innovation in the areas of products, services, processes, management, and marketing permits SMEs overcome the existing competition in its industry, enabling the business to grow and gain market share at the expense of firms that do not innovate [55-59]. By growing and gaining market share, the improved market position of the firm improves corporate performance by being able to build up a monopolistic rent [60-63].

Consistent with the mechanisms explained above, the recommendation of product, process, and/or marketing innovation has been shown to be significantly and positively related to firm growth in entrepreneurial SMEs [64]. The introduction of product innovations enables firms to attract new customers in current and/or new market bases, increasing their market share and resulting in sales growth which leads to increased profits [65-72]. Introducing market innovations generates turnover through collective intake of the firms' products [73]. This also suggests that product and marketing innovations may need to work hand in hand as introducing innovations in new products may also require the ability to penetrate new markets, which can be provided by marketing innovations [70]. Implementing process innovations increases proceeds on behalf of the organization through sound abilities and decreasing expenditures [65]. Introducing management innovations plays a key role in an organizations' innovative capabilities by creating new organizational structures that facilitate the development of innovations in other areas [73]. To complete this, the study compared the dimension of Entrepreneurial Marketing (EM), with the construct of EO. The five dimensions, namely proactiveness, innovativeness, autonomy, competitive aggressiveness and risk-taking, were found to overlap and have a strong impact on firm performance [68]. Consequently, the study focus on those five $\mathrm{EO}$ dimensions to examine the influence of EO on marketing innovation performance in SMEs. The following sections will introduce each dimension in details.

\section{Innovativeness in marketing innovation}

Indeed, innovativeness is highly related to the "organization's tendency to engage in and support new ideas, novelty, experimentation, and creative processes that may result in new products, services or technological processes, as well as the pursuit of creative, unusual, or new solutions to problems and needs" [74]. In other words, technological development or product innovation can be utilized when pursuing new opportunities or seizing a competitive advantage [75,76]. Prior studies propose that new firms will build amazing performance, cost-effectiveness and relate resourcefulness in the business atmosphere [77,78]. To sum up, by looking at the magnitude of change it will bring to SME, it is justifiable to place EO as a strong variable towards SMEs marketing innovation Performance. Therefore, based on the literature above, the following hypothesis is proposed:

H1a: Innovativeness has a significant positive impact on SMEs marketing innovation performance.

\section{Proactiveness in marketing innovation performance}

Proactiveness is described with a great level of opportunity-seeking enterprise that, preferably, are ahead of their opponents and effectively forestall future client demands. Meanwhile, Covin and Miller [79] submit that organizations must have the planned reactiveness and alertness to fresh conditions that often occur in unclear entrepreneurial perspectives. Prior studies have establish that proactive companies can accomplish their objectives in best segments, move faster to sustain an advantage, capitalize a market prospect for greater yields, and be a groundbreaker in performance $[80,81]$. Achieve better performance because they have a greater understanding of customer needs and wants, and broader market environment than their competitors [82]. Thus, the following hypothesis is proposed:

H1b: Proactiveness has a significant and positive impact on SMEs marketing innovation performance.

\section{Risk taking in marketing innovation performance}

According to Eggers et al. [83], risk-taking refers to the organization's agreement to commit resources with uncertain outcome. Morrish [84] states that risk-taking implies a company's propensity to offer a product that is not well known or accepted within the market. In other words, a company might take a risky strategy when introducing a product, which serves customer needs that do not yet exist, rather than solely serving expressed customer needs. However, in order to obtain a competitive advantage, businesses need to take a risk to some extent, e.g., introducing new products or services in new markets [85-87]. Complement an affirmative relationship between risk-taking and firm performance. In this logic, submit that pioneering SMEs must minimize the level of threat and take act to evade tasks that are excessively hazardous to achieve better performance. Thus, the following hypothesis is proposed:

H1c: Risk-Taking has a significant and positive impact on SMEs marketing innovation performance.

\section{Competitive aggressiveness in marketing innovation performance}

The strength of a firm's struggles to outperform business competitors and taking them head-on at every chance is defined as competitive aggressiveness. It is characterized via a robust aggressive posture, which is directed at disabling opponents [86]. Venkatraman [87] proposed that competitive aggressiveness is accomplished by setting motivated market share goals and taking gallant steps to achieve them, such as cutting prices and forgoing profitability. The relationship between competitive aggressiveness and firms' performance seems to be quite debatable. Several author showed a positive link between these two dimensions [74] however some other have establish a null relationship between competitive aggressiveness and firms performance. Therefore, the following hypothesis is proposed:- 
Citation: Musawa MS, Ahmad K (2018) A Conceptual Framework for the Influence of Entrepreneurial Orientation and Environmental Dynamism on Marketing Innovation Performance in SMEs. Bus Eco J 9: 361. doi:10.4172/2151-6219.1000361

Page 5 of 8

H1d: Competitive aggressiveness has a significant and positive impact on SMEs marketing innovation performance.

\section{Autonomy in marketing innovation performance}

This reveals the "independent spirit" including the idea of open and independent action and decision taken [17,33]. Concerning the autonomy dimension of EO, several studies have confirmed that autonomy is positively linked to firms' performance nevertheless further researchers do not confirm such effects. The varied nature of this relationship showed the need to improve knowledge about this link. In this paper the following hypothesis is proposed:

H1e: Autonomy has a significant and positive impact on SMEs marketing innovation performance.

\section{Research Framework}

In line with the propositions, the following conceptual framework is developed. This study used a conceptual framework developed by authors based on previous studies on the influence of EO and environmental dynamism on marketing innovation performance in the context of SMEs. EO is considered as independent variable while marketing innovation performance is considered as dependent variable. The study is backed by two theories, namely Resource-Based View (RBV) and Contingency Theory. The combination of the two theories in the study provided a platform for investigating the influence of environmental dynamism being an external organizational factor on the relationship between EO and marketing innovation performance (Figure 1).

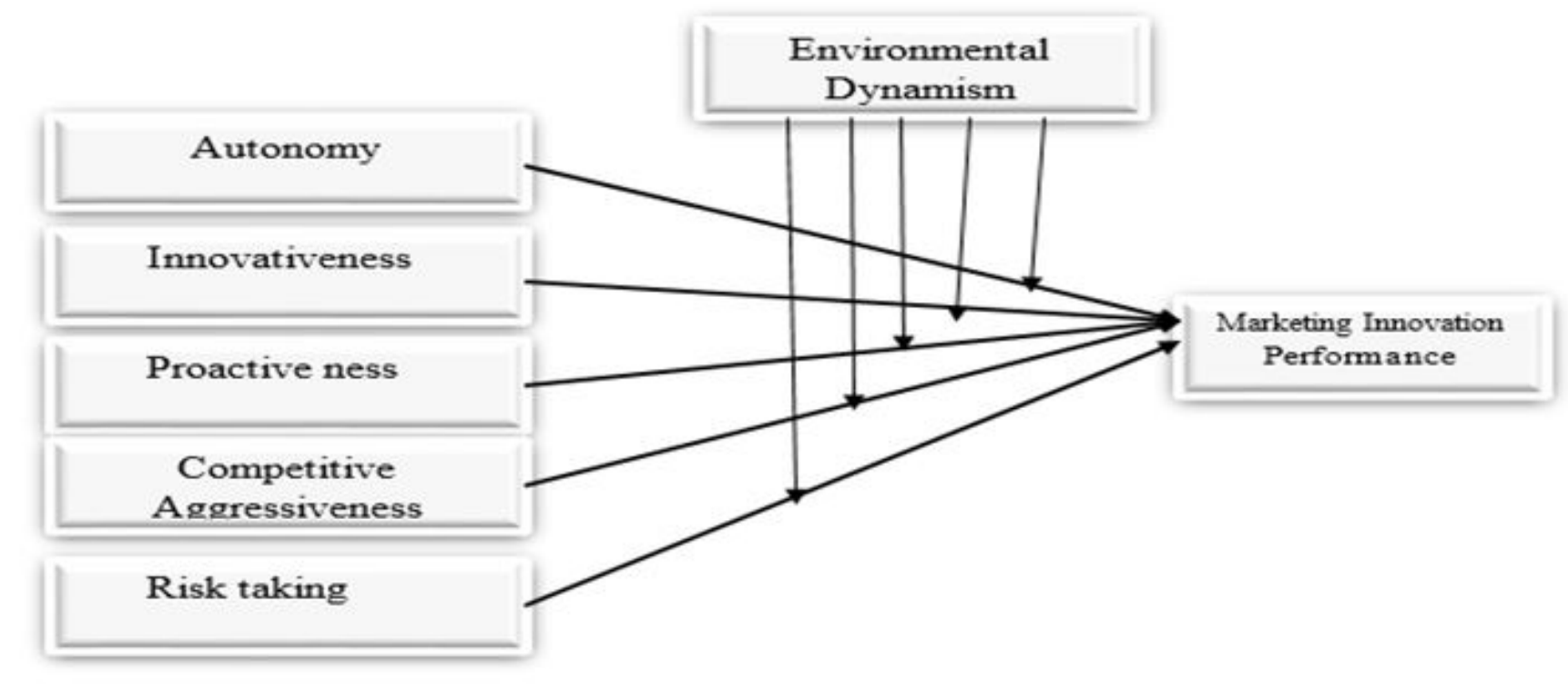

Figure 1: Proposed model.

\section{Conclusion}

SMEs business represent an important source of growth and development for the economies worldwide. This paper attempts to describe the vital role of these variables in improving SMEs marketing innovation performance. Therefore, a conceptual framework for the realization of the research objective was developed. In the current literature, EO can be taken by the tendency to act autonomously, the propensity to be aggressive toward competition, to proactively follow market openings, and to have the readiness to transform and bear the risk.

The significance of the accurate model for SMEs will help to boost the potential of its resources and improve business marketing innovation performance. Growing the marketing innovation performance of SMEs was influenced by changes in the dynamic environment, through the EO of the SMEs owner-managers. The external environment has an enormous influence on the business activity of SMEs. Changes in consumer tastes and the movement of competitors is an indication of the increasingly dynamic business environment.
This study offers some important contributions to literature as it examines the influence of $\mathrm{EO}$ and environmental dynamism on marketing innovation performance in SMEs. This study has become unique in the sense that it examines the moderating effect of environmental dynamism. The study is undergoing a confirmation process that will benefit policy makers, regulatory bodies, and SMEs owner-managers. Based on the literature reviews established by this study, it is concluded that there is a strong and significant positive correlation between EO and marketing innovation performance among SMEs. Nevertheless, this study did not focus on SMEs from specific industry thus further studies are invited. SMEs should be able to make a strategic move as the basis for making the right decisions in order to survive and have high competitiveness. Based on the findings from this study the following recommendations are made.

It is therefore clear SMEs should develop business culture and organization styles intended at the advertising of pioneering, proactive and risk-taking performance. SMEs owner managers should be able to evaluate their needs and match them accordingly to the strategy chosen. Future studies should be done in order to find out what other strategies can be implemented in order to help SMEs firm stay 
profitable. Most of the researchers have been able to find a positive EO performance relationship that gets stronger over time and many moderating factors have been found to strengthen the relationship. It is hoped that the research insights in this review will provide a framework for further productive discussion and for more empirical studies on the EO Concept.

\section{Acknowledgements}

The researcher is greatly indebted to Research Management Institute (OREC), UTHM and CGS Universiti Tun Hussein Onn Malaysia for providing the financial support throughout this study.

\section{References}

1. Wiklund J, Shepherd D (2005) Entrepreneurial orientation and small business performance: a configurational approach. J Bus Venturing 20: 71-91.

2. Soininen J, Kaisu P, Helena S, Pasi S, Sussane D (2013) Entrepreneurial Orientation in Small Firms; Values-Attitudes-Behavior Approach. Int J Entrepreneurial Behav Res 19: 611-632.

3. Dada O, Watson A (2013) Entrepreneurial orientation and franchise system: Organizational antecedents and performance outcomes. Eur J Market 47: 792-793.

4. Mfaume RM, Leonard W (2004) Small Business Entrepreneurship in Dar Es Salaam -Tanzania: Exploring Problems and Prospects for Future Development, African development and poverty reduction, the macromicro linkage, forum paper 2004, 13-15, October 2004, Lord Charles Hotel, Somerset West, South Africa.

5. Ireland D, Hitt MA, Sirmon DG (2003) A model of strategic entrepreneurship: The construct and its dimensions. J Manage 29: 963-989.

6. Dalberg (2011) Report on Support to SMEs in Developing Countries through Financial Intermediaries.

7. Vanhaverbeke W, Vermeersch I, De Zutter S (2012) Open innovation in SMEs: How can small companies and start-ups benefit from open innovation strategies? Res Rep, p: 9.

8. Abdallah AB, Obeidat BY, Aqqad NO (2014) The Impact of Supply Chain Management Practices on Supply Chain Performance in Jordan: The Moderating Effect of Competitive Intensity. Int Bus Res7: 13-27.

9. Kraus S, Harms R, Fink M (2010) Entrepreneurial marketing: moving beyond marketing in new ventures. Int J Entrepreneurship Innov Manage 11: 19-34.

10. García-Zamora E, González-Benito Ó, Muñoz-Gallego PA (2013) Organizational and environmental factors as moderators of the relationship between multidimensional innovation and performance. Innov 15: 224-244.

11. Zheltoukhova K, Suckley L (2014) Hands-on or hands-off: effective leadership and management in Small to Medium size Enterprises, Chartered Institute of Personnel and Development (CIPD).

12. Hauser J, Tellis GJ, Griffin A (2005) Research on innovation: A review and agenda for Marketing Science. Marketing Science 25: 687-717.

13. Evans SJ (1991) Strategic flexibility for high technology maneuvers: a conceptual framework. Journal of Management Studies 28: 69-89.

14. Rauch A, Wiklund J, Lumpkin GT, Frese M (2009) Entrepreneurial orientation and business performance: An assessment of past research and suggestions for the future. Entrepreneurship Theory and Practice 33: 761-787.

15. Webb JW, Kistruck GM, Ireland RD, Ketchen Jr DJ (2010) The entrepreneurship process in a base of the pyramid markets: The case of multinational enterprise/nongovernment organization alliances. Entrepreneurship Theory and Practice 34: 555-581.

16. Jantunen A (2005) Knowledge-processing capabilities and innovative performance: an empirical study. European Journal of Innovation Management 8: 336-349.
17. Lumpkin GT, Dess GG (1996) Clarifying the entrepreneurial orientation construct and linking it to performance. Academy of Management Review 21: 135-172.

18. Soininen J, Martikainen M, Puumalainen K, yläheiko KK (2012) Entrepreneurial orientation: Growth and profitability of Finnish smalland medium-sized enterprises. International Journal of Production Economics 140: 614-621.

19. Zainol FA, Daud WD (2011) Indigenous ("Bumiputera") Malay entrepreneurs in Malaysia: Government supports, entrepreneurial orientation and firms performance. International Business and Management 2: 86-99.

20. Gima K, Anthony K (2001) An Empirical Investigation of the Effect of Market Orientation and Entrepreneurship Orientation Alignment on Product Innovation. Organ Science 12: 54-74.

21. Alarape AA (2014) Developing the entrepreneurial orientation of ownermanagers of small and medium enterprises in Nigeria. IFE PsychologIA: Int J 22: 218-231.

22. Lumpkin GT, Dess GG (2001) Linking two dimensions of entrepreneurial orientation to firm performance: the moderating role of environment and industry life cycle. Journal of Business Venturing 16: 429-451.

23. Li H, Atuahene-Gima K (2001) Product innovation strategy and the performance of new technology ventures in China. The Academy of Management Journal 44: 1123-1134.

24. Schweitzer FM, Gassmann O, Gaubinger K (2011) Open innovation and its effectiveness to embrace turbulent environments. International Journal of Innovation Management 15: 1191-1207.

25. Li M, Simerly R (1998) The moderating effect of environmental dynamism on the ownership and performance relationship. Strategic Management Journal 19: 169-179.

26. Akgün AE, Keskin H, Byrne J (2009) Organizational emotional capability, product and process innovation, and firm performance: an empirical analysis. J Eng Tech Manage 26: 103-130.

27. Camisón C, Villar-López A (2012) Organizational innovation as an enabler of technological innovation capabilities and firm performance. J Bus Res 67: 2891-2902.

28. Spillan J, Parnell J (2006) Marketing resources and firm performance among SMEs. European Management Journal 24: 236-245.

29. Makadok R (2001) Toward a synthesis of the resource-based and dynamic-capability views of rent creation. Strategic Management Journal 23: $387-401$.

30. Gopalakrishnan S (2000) Unraveling the links between dimensions of innovation and organizational performance. J High Technol Manage Res 11: 137-153.

31. Frese M, Brantjes A, Hoorn R (2002) Psychological success factors of small-scale businesses in Namibia: The roles of strategy process, entrepreneurial orientation, and the environment. J Dev Entrepreneurship 7: 259-278.

32. Davis JL (2007) Firm-level entrepreneurship and performance: An examination and extension of relationships and measurements of the entrepreneurial orientation construct. Unpublished Thesis, University of Texas.

33. Callaghan C, Venter R (2011) An investigation of the entrepreneurial orientation, context and entrepreneurial performance of inner-city Johannesburg street traders. South Afr Bus Rev 15: 28-48.

34. Abiodun EA (2014) The role of SME firm performance in Nigeria. Arab J Bus Manage Rev 3: 33-47.

35. Agwu OM, Emeti IC (2014) Issues, challenges, and prospects of small and medium scale enterprises (SMEs) in Port-Harcourt city, Nigeria. Eur J Sustain Dev 3: 101-114.

36. Ayyagari M, Beck T, Demirgüç-Kunt A (2007) Small and Medium Enterprises Across the globe: a new database. Small Bus Econ 29: 415-434.

37. Baron RA, Tang J (2011) The role of entrepreneurs in firm-level innovation: Joint effects of positive affect, creativity, and environmental dynamism. J BusVenturing 26: 49-60. 
38. Ruiz- Ortega MJ, Rodrigo-Alarcon J, Garcia-Villaverde PM (2013) Environmental dynamism and entrepreneurial orientation: The moderating role of firm's capabilities. Journal of Organization Change Management 26: 475-493.

39. Mitchell J, Shepherd D, Sharfman M (2011) Erratic strategic decisions: Managers are inconsistent in strategic decision making. Strategic Management Journal 32: 683-704.

40. Azadegan A, Patel P, Zangoueinezhad A, Linderman K (2013) The effect of environmental complexity and environmental dynamism on lean practices. J Oper Manage 31: 193-212.

41. Patel P, Azadegan A, Ellram L (2013) The effects of strategic and structural supply chain orientation on operational and customer-focused performance. Decision Sciences Journal 44: 713-753.

42. Gaur S, Vasudevan H, Gaur A (2011) Market orientation and manufacturing performance of Indian SMEs. Eur J Market 45: 1172-1193.

43. Qi Y, Zhang M (2010) The impact of manufacturing strategy on mass customization: Moderating effect of environmental uncertainty. International Journal of Decision Science 1: 113-133.

44. Sanders JJL, Linderman K (2014) Process management, innovation and efficiency performance: The moderating effect of competitive intensity. Business Process Management Journal 20: 335-358.

45. Carter S, Jones-Evans D (2006) Enterprise and Small Business: Principles, Practice, and Policy (2nd Ed.) .Harlow: Prentice Hall.

46. Lee LTS (2011) The effects of environmental dynamism and team strain on product innovation: The moderating role of perceived diversity climate. African Journal of Business Management 5: 8740.

47. Fairoz FM, Hirobumi T, Tanaka Y (2010) Entrepreneurial Orientation and Business Performance of Small and Medium Scale Enterprises of Hambantota District Sri Lanka. Asian Soc Sci.

48. Oslo Manual: Guidelines for Collecting and Interpreting Innovation Data. Organization for Economic Cooperation and Development 2007.

49. Gitau G, Mukulu E, Kihoro J (2016) Influence of entrepreneurial orientation on competitive advantage among mobile service providers in Kenya. Int J Manage Commerce Innov 3: 2010-2016.

50. Gürbüz G, Aykol S (2009) Entrepreneurial management, entrepreneurial orientation and Turkish small firms growth. Manage Res News 32: 321-336.

51. Hamisi S (2011) Challenges and opportunities of Tanzanian SMEs in adapting supply chain management. Afr J Bus Manage 5: 1266- 1276.

52. Haron DH, Ismail DI, Khalid SNA, Ganesan Y (2010) Cases of successful Malaysian small and medium enterprises (SMEs): Does business advisory services help? Malaysia Accountancy Research and Education (MAREF).

53. Hatten TS (2011) Small Business Management: Entrepreneurship and Beyond (5th Ed.). Mason: South-Western Cengage Learning.

54. Helfat C, Finkelstein S, Mitchell W, Peteraf MA, Singh H et al., (2007) Dynamic Capabilities: Understanding Strategic Change in Organizations, Blackwell, and Oxford, UK.

55. Huang SK, Wang YL (2011) Entrepreneurial orientation, learning orientation, and innovation in small and medium enterprises. Procedia Social and Behavioral Sciences 24: 563-570.

56. IEG (2008) Financing micro, small, and medium Enterprises: An Independent Evaluation of IFC's experience with financial intermediaries in frontier Countries. Independent Evaluation Group, the International Finance Corporation, World Bank Group.

57. Keh HT, Nguyen TTM, Ng HP (2007) The effects of entrepreneurial orientation and marketing information on the performance of SMEs. Journal of Business Venturing 22: 592-611.

58. Kuratko DF, Ireland RD, Hornsby JS (2001) Improving firm performance through entrepreneurial actions: Acordia's corporate entrepreneurship strategy. Academy of Management Executive 15: 60-71.

59. Kushnir K, Mirmulstein ML, Ramalho R (2010) Micro, small, and medium Enterprises around the world: how many are there, and what affects the count? MSME Country Indicators. World Bank / IFC.

60. Li YH, Huang JW, Tsai MT (2009) Entrepreneurial orientation and firm performance: The role of knowledge creation process. Industrial Marketing Management 38: 440-449.

61. Lyon DW, Lumpkin GT, Dess GD (2000) Enhancing entrepreneurial orientation research: Operationalizing and measuring a key strategic decision-making process. Journal of Management 26: 1055-1085.

62. Madatta JS (2011) The Role of Entrepreneurial Competencies on the Success of the SME's In Tanzania: The Case Study of Ilala and Temeke Municipals, Master's thesis, Open University in Tanzania.

63. Moreno-Luzon MD, Gil-Marques M, Valls-Pasola J (2013) TQM, innovation and the role of cultural change. Industrial Management \& Data Systems 113: 1149-1168.

64. Njoku AC, Ihugba OA, Odii A (2014) Theoretical analysis of entrepreneurship challenges and prospects in Nigeria. International Letters of Social and Humanistic Sciences, pp: 21-34.

65. Nwankwo S, Gbadamosi T (2011) Entrepreneurship marketing: Principles and practice of SME marketing. Abington: Rout ledge.

66. Ong JW, Ismail HB, Goh GGG (2010) The competitive advantage of any luck. Journal of Small Business Entrepreneurship 23: 373-391.

67. Pérez-Luño A, Wiklund J, Cabrera RV (2011) The dual nature of innovative activity: How entrepreneurial orientation influences innovation generation and adoption. Journal of Business Venturing 26: $555-571$

68. Schneider S, Spieth P (2013) Business model innovation: Towards an integrated future research agenda. International Journal of Innovation Management 17: 1340001.

69. Sheikh M, Hasnu S, Khan I (2016) A link between HR practices and organizational performance in small firms: A case for the manufacturing sector of Pakistan. Management Science Letters 6: 71-86.

70. Subhan QA, Mehmood MR, Sattar A (2013) Innovation in Small and Medium Enterprises (SME's) and its impact on Economic Development in Pakistan. In Paper was presented at 6th International Business and Social Sciences Research Conference, pp: 3-4.

71. Janet $T$ (2005) Marketing Innovation: The Construct, Antecedents and Consequences.

72. Walter A, Auer M, Ritter T (2006) The impact of network capabilities and entrepreneurial orientation on university spin-off performance. Academic Entrepreneurship, pp: 9-45.

73. Gunday G, Ulusoy G, Kilic K, Alpkan L (2011) Effects of innovation types on firm performance. Int J Prod Eco 133: 662-676.

74. Madhoushi M, Sadati A, Delavari H, Mih M, Ost R (2011) Entrepreneurial Orientation and Innovation Performance: The Mediating Role of Knowledge Management. Asian Journal of Business Management 3: 310-316.

75. Lechner C, Gudmundsson SV (2014) Entrepreneurial orientation, firm strategy and small firm performance. International Small Business Journal 32: 36-60.

76. Thoumrungroje A, Racela O (2013) The contingent role of customer orientation and entrepreneurial orientation on product innovation and performance. Journal of Strategic Marketing 21: 140-159.

77. Krauss SI, Frese M, Friedrich C, Unger JM (2005) Entrepreneurial orientation: A psychological model of success among southern African small business owners. European Journal of Work and Organizational Psychology 14: 315-344.

78. Palacios-Marques D, Saldaña AZ, Vila JE (2013) What are the relationships among Web 2.0, market orientation and innovativeness? Kybernetes 42: 754-765.

79. Covin JG, Miller D (2014) International entrepreneurial orientation: conceptual considerations, research themes, measurement issues, and future research directions. Entrepreneurship Th Pract 38: 11-44. 
Citation: Musawa MS, Ahmad K (2018) A Conceptual Framework for the Influence of Entrepreneurial Orientation and Environmental Dynamism on Marketing Innovation Performance in SMEs. Bus Eco J 9: 361. doi:10.4172/2151-6219.1000361

Page 8 of 8

80. Brettel M, Rottenberger JD (2013) Examining the link between entrepreneurial orientation and learning processes in small and mediumsized enterprises. J Small Bus Manage 51: 471-490.

81. Chen YC, Li PC, Evans KR (2012) Effects of interaction and entrepreneurial orientation on organizational performance: insights into market driven and market driving. Ind Market Manage 41: 1019-1034.

82. Khalili H, Nejadhussein S, Fazel A (2013) The influence of entrepreneurial orientation on innovative performance: Study of a petrochemical company in Iran. Journal of Knowledge-based Innovation in China 5: 262-278.

83. Eggers F, Kraus S, Hughes M, Laraway S, Snycerski S (2013) Implications of customer and entrepreneurial orientations for SME growth. Manage Decision 51: 524-546.
84. Morrish SC (2011) Entrepreneurial marketing: a strategy for the twentyfirst century? Journal of Research in Marketing and Entrepreneurship 13: 110-119.

85. Dess GG, Lumpkin GT (2005) The role of entrepreneurial orientation in stimulating effective corporate entrepreneurship. Acad Manage Exec 19: 147-156.

86. Lumpkin GT, Dess GG (1997) Proactiveness versus competitive aggressiveness: Teasing apart key dimensions of an entrepreneurial orientation. Frontiers of Entrepreneurship Research, pp: 47-58.

87. Venkatraman N (1989) Strategic orientation of business enterprises: the construct, dimensionality, and measurement. Management Science 35: 942-962. 